OPEN ACCESS

Edited by:

Scott Schaffer,

University of Western Ontario, Canada

Reviewed by:

Yi-Tung Chang,

National Pingtung University, Taiwan

Sarah Burton,

Durham University, United Kingdom

*Correspondence:

Andreu Domingo

andreu.domingo@gmail.com

Specialty section:

This article was submitted to

Sociological Theory

a section of the journal

Frontiers in Sociology

Received: 18 April 2018

Accepted: 03 July 2018

Published: 26 July 2018

Citation:

Domingo A (2018) Analyzing Zombie Dystopia as Neoliberal Scenario: An

Exercise in Emancipatory

Catastrophism. Front. Sociol. 3:20.

doi: 10.3389/fsoc.2018.00020

\section{Analyzing Zombie Dystopia as Neoliberal Scenario: An Exercise in Emancipatory Catastrophism}

\author{
Andreu Domingo* \\ Centre for Demographic Studies, Barcelona, Spain
}

This article starts with a hypothesis that the sociological analysis of literary and film production on the "living dead" in the 21st century, owing to the triumph of neoliberalism that has accompanied by the process of globalization, allows us to better understand the transformations that act on the population and the individuals that integrate it. The zombie genre, considered a dystopia -where the scenario of the uncertainty surrounding the risk has happened to that of the catastrophe- reflects the split between resilient and redundant population, inviting us to explore three fundamental features: (1) the causes of this split; (2) The construction of a new subjectivity that accompanies it; and, (3) the displacement of bio politics to the thanatopolitics that accounts for the fracture between liberalism and neoliberalism. Dystopian thinking, based on detecting the germs of negative evolutions in the present, the causes and their possible consequences, posing different scenarios for the future, can be understood as a method of cosmopolitan sociological analysis, which ends in what Ulrich Beck described as "emancipatory catastrophism," that is, not only to identify the seeds of the negative, but the good of the bad.

Keywords: global theory, cosmopolitanism, population, zombie genre, futures

\section{DYSTOPIA AS A METHOD: A BLUE LIGHT CROSSING THE DARKNESS}

The main objective of this text is to analyze the productions of the zombie genre in the twenty first century, based on the hypothesis that has become dystopia that explores the extreme effects of neoliberalism on the populations, on the government, and on the process of subjectivation. This objective is complemented by the hypothesis that the dystopian procedure -identification of negative tendencies, analysis of the implications of governance and individuals, and the construction of possible future scenarios- constitutes in itself a method that connects with the origin of sociology. The hermeneutic interrogation has been determined as the commonplace of a sociology that was in the 19th century at the crossroads between the literary and the scientist field (Lepenies, 1988). The difference between the construction of fiction and the sociological method is that while the former adopts rules of the game established in the metaphorical literary genre, the second one is concerned with the analysis of the social conditions of its production and perception. The weight of the film industry in the production of zombie fiction in the twenty first century adds a particular element as it responds much more easily to the dialogue that holds with the public in the form of an audience, representing societal dynamics that reflect social imaginary significations (Southerland and Feltey, 2013). 
Almost 30 years after the "end of history" was announced (Fukuyama, 1989) and, with it, the shrinking of time, anxieties about the possibility of a future and the struggle to conquer it have once again occupied the foreground, whether they take the form of blueprints for utopia or disenchanted utopias, which turn out to be dystopias after all. In this context the sociologist Ulrich Beck left as his legacy the proposal of what he called "emancipatory catastrophism" in his posthumous work The Metamorphosis of the World: How Climate Change Is Transforming Our Concept of the World (Beck, 2016). Essentially, he writes about changes in the way we see the world, in relation with the theory of the risk society, cosmopolitanism, and individualization under the impact of catastrophe and, most especially, global warming. We are thus invited to conceptualize the experience of catastrophe as an element that enables us to become aware of a new emerging world, and to orient our scientific inquiry and political praxis toward the (eminently utopian) terrain of emancipation. The theory of "Metamorphosis of the World" goes beyond the theory of "risk society" which Beck formulated at the end of the twentieth century (Beck, 1986). One can consider that it represents the maturation of the theory of second modernization or reflective modernity, according to which there is a radical change in industrial society, taking to its last consequences the process of modernization (Beck, 1994). The displacement of the prevention of resilience pointed out by geographer Amin (2012), would eventually culminate the triumph of neoliberalism, to end up giving his attention to the positive effects of risk when it becomes catastrophe (bearing its inevitability in mind).

"Emancipatory catastrophism" the term Beck uses in The Metamorphosis of the World, can be considered as a method that transforms the dystopian perspective into a tool for analyzing reality and exploring the positive aspects-which are invisible to us-of global risk or catastrophe or, to use Beck's words, "the positive side effects of bads," making it possible both to anticipate and create the future. A similar idea was outlined 6 years earlier by Fredric Jameson who, speaking of utopia as a method, noted that: "The operation itself, however, consists in a prodigious effort to change the valences on phenomena that so far exist only in our own present and experimentally to declare positive things that are clearly negative in our own world, to affirm that dystopia is in reality utopia if examined more closely, to isolate specific features in our empirical present so as to read them as components of a different system" (Jameson, 2010, p. 42). Although in their respective arguments each writer refines the concept in accordance with his own baggage, the considerable convergence between them should not be surprising if one bears in mind that they draw on the same sources, namely the concept of the utopian impulse as the "principle of hope" described by Bloch (1995) and, still more, the Marxist dialectic from which the latter also derived his thought: the idea that capitalism would engender the conditions for its own abolition. The long, roundabout route which led both authorsmore or less explicitly-to recognize dystopia as emancipatory method should be explained by a predilection for the principle "utopian" with which, for ideological reasons, they felt more closely identified.
This discussion has been traversed by the relationship between "ideology and utopia", which is explicit in the classic study by Manheim (1936) with precisely this title and, specifically, in considerations of the emancipatory potential of utopias in the form of both political programs and works of fiction. The origins and consolidation of dystopias in the first half of the twentieth century as a reaction to the emergence of totalitarianism earned them the label of anti-utopias. In other words, after the publication of We by Yevgeny Zamyatin in 1921, Brave New World by Aldous Huxley in 1932, and George Orwell's Nineteen Eighty-Four in 1948, to mention just three of the most famous works, dystopia was suspected of being ideologically alienated from the emancipatory projects which had been known as utopias, thus leading some authors to discriminate between "antiutopian dystopias" and "critical dystopias" as variants of utopia (Moylan, 2000; Orwell, 2000; Huxley, 2004; Zamyatin, 2006). The geographer Schlosser (2015), analyzing ideology and dystopia and specifically in apocalyptic scenarios, discusses the division among those who hold that an apocalypse could open the way to revolutionary potentials as suggested by etymology deriving from the Greek word $A \pi \circ \kappa \alpha \lambda v \psi \iota \varsigma$, meaning "revelation," in which case it is seen as capable of shattering illusion as an essential mechanism of social reproduction and stratification (Bourdieu, 2012) and, consequently, of inequalities (Noxolo and Preziuso, 2013; Strauss, 2015). At the other end of the scale are people who view these same dystopias as an interpretive foreclosure in the service of post-politics and depoliticization (Wilson and Swyngedouw, 2014). Schlosser concludes that the ideological intentionality of dystopias must be understood through the historical context so that the genre as such does not become an a priori "bearer" or "expression" of a particular ideology. The same might be said of the zombie genre transformed into a population-based dystopia.

Attempts have been made from sociology and history to define utopia as a method, in two different but interconnected ways. From history, analysis of utopias/dystopias is proposed "for what they reveal about a set of abiding concerns and cultural formations that generated both the desire for utopian transcendence and the specific form that utopia/dystopia took" (Gordin et al., 2010, p. 4), but also as markers of the conditions for the possibility of a future. From the standpoint of sociology, Levitas (2013) argues that philosophical and literary utopias can be seen as a method of sociological analysis in three approaches which she calls "archeological," "ontological," and "architectural." In the first, she refers to the compilation of images of desirable societies which may be found in political programs or socioeconomic praxis. Her second category is an ontological modality inasmuch as utopias (and dystopias) are investigated for the kind of individuals that produce them and that are produced by them. The third, architectural, approach explores the construction of future scenarios which could be interpreted as conditions for the possibility of a future. What is stated for utopias can also be applied to dystopias with the differentiating factor that dystopia always raises an elusive approximation. In terms of Beck, we can say that Risk speaks in a dystopic language: telling us what should not be done (but not what should be done). 
My first hypothesis is that, in the third millennium, the zombie genre has undergone transformation to take into account the division between zombies and survivors, showing an increasing fascination for the conditions of individual and collective survival, otherwise known as resilience, as one of the great concerns imposed on the planetary scale by the triumph of neoliberalism. A second hypothesis would be that the worldwide success of the zombie genre now transformed into a demographic dystopia is not only due to the fact that it reflects the fears of the contemporary world-terrorism, downward mobility, and ethnic substitution, for example-but also something brought to light by analysis of fiction coming under the heading of dystopian, namely a crossover between the "technologies of power" (government and definition of populations) and the "technologies of the self" (in the process of subjectivation), to use the terms of Foucault (1988). In other words, dystopia can be seen as a method of critical analysis of reality, first, in making visible undesirable trends which affect the evolution of the population and, then, by projecting them into the future. Hence, it presents the keys for intervening in and changing this adverse evolution. Finally, a third hypothesis would be that we are being alerted to the transformation of biopolitics into its thanatological version, which then requires examination of the conditions in which global power is exercised and determining who is dispensable or who will become a reject of the system (Mbembe, 2006). In the following sections I therefore aim to discuss twenty-first-century dystopian productions and, in particular, the zombie genre as a cosmopolitan sociological method oriented to an unknown future, in order to analyze the main transformations acting on populations and the individuals that comprise them, how they are governed, and the emancipatory seeds they may contain.

To sum up, my aim, following Beck and Levitas, is to study the zombie genre as a demodystopia, carrying out a critical analysis of the negative trends deriving from economic globalization and the triumph of neoliberalism in order to turn it into an exercise of "emancipatory catastrophism" along the lines of cosmopolitan sociology-defined as that which is reoriented toward an unknown future to make it present on the temporal horizon of global risk-as Beck postulated.

\section{THE ARCHAEOLOGICAL FILE}

What negative (undesirable) images can be collected in political discourse and works of science fiction concerning the evolution of population in the twenty first century? How does one confront these trends? What do these images say about the transformation of the concept of population and evaluation of different demographic phenomena as threats?

\section{From Overpopulation to Global Risk in the Twenty First Century}

Overpopulation was indisputably the main theme of demodystopias in the twentieth century (Domingo, 2008). Yet, with awareness of a generalized decline in fertility and a slowdown in world population growth, the demographic explosion gave way to other concerns like global warming. This is not to say that demography disappeared from the scene but rather that the still-growing population-estimated at 6 billion at the beginning of the third millennium and 7.632 billion in 2018, according to the latest United Nations figures (2017) would now appear as a detonator linked with the ecological catastrophe, and that other demographic phenomena deriving from structure-mainly population aging-and dynamicsmigration and decline in fertility in particular-would take center stage, this time under the heading of global risks. The most alarmist expression of this is to be found in the work of the British geophysicist James Lovelock and his controversial Gaia hypothesis $(2007 ; 2010)$, according to which the human population exceeded the planet's capacity for self-regulation some time ago. Then again, the naturalist Attenborough (2011) declared that the humans are a plague on the Earth and their population must be drastically reduced if we are to avoid collapse.

Yet there can be no doubt that the global risks reports published since 2006 by the World Economic Forum and presented each year at the Davos Summit are the best symptoms of the way in which demographic evolution has been transformed into a global risk (Domingo, 2015). Hence, apart from population growth, the leading demographic threats (related with consumption that is both senseless and unsustainable) one finds featuring in the 12 years of these reports are economic migrants and refugees (increasingly linked with global warming but also terrorism), imbalances in population structure by age (especially with regard to aging, although the young population is also viewed with some wariness), and the growth of urban population and megalopolises with their corollary of increasing inequality. The high point of all this came in 2012 when the core dossier, titled "Seeds of Dystopia", presented demographic evolutionpopulation growth, aging, and fast increasing urbanization-as a potentially explosive causal factor (World Economic Forum, 2012). The impact of these three elements on the job market (scarcity of young people), fiscal imbalance, and growing inequality (also by generations) was leading to blowback in the globalization process and increasingly fragile states. The report went so far as to suggest a geopolitical taxonomy depending on the phase in which each country was located in terms of the demographic transition, since it was population structure that marked the destiny and hierarchy in each country. At the top of the list were the post-transitional and developed countries with the challenges of aging, followed by those that had begun lengthening life expectancy and reducing fertility, identified as the emergent countries where the development of the labor market to provide work for young people and persisting inequality were singled out as the main challenges and, at the bottom, were countries that had just embarked on the demographic transition, threatened by terrorism and instability owing to a high proportion of young people who constituted, on the rebound, a threat for other countries to which this population was being expelled. In 2015, the growth of urban population came to the foreground as a major threat, coinciding with an announcement by the United Nations that it now exceeded more than $50 \%$ of the world's total population (World Economic Forum, 2015). The $2016 \mathrm{WEF}$ report placed involuntary migration in top place in its ranking of the most 
probable risks and, regarding impact, in second place only to climate change caused by global warming (World Economic Forum, 2016). And it should be recalled here that the refugee crisis came to a head in the summer of 2015. The lowest level appears, perhaps, in the 2018 report in which some of these demographic risks are designated as "simple" trends: aging, accelerated geographic mobility, urban population growth, and their possible association with other global risks to produce a "cascade of risks" endangering the interconnection between various complex systems of adaptation (World Economic Forum, 2018).

The global risks reports are eminently relational since they are established on the basis of analyzing networks of answers to surveys addressed to qualified informants-scientists, businesspeople and politicians-who are asked to identify risks, the probability of their materialization, and the possible influences among them. In other words, they are not so concerned about the reasons why a particular phenomenon might become a global risk, but its future conditions, the impact it might have, and its presumed correlation with other global risks. The main concern, as the different risks-and not only demographic-are being defined, is coming up with strategies for confronting them. This is where the concept of "resilience" appears, referring at first to any complex system-businesses, transport systems, financial systems and the state-but it is not long before one finds it specifically applied to population and the individuals comprising it. Resilience is understood as "the capability to (1) adapt to changing contexts, (2) withstand sudden shocks, and (3) recover to a desired equilibrium, either the previous one or a new one, while preserving the continuity of its operations" (World Economic Forum, 2013, p. 37). Resilience would come to be presented as the ultimate aim of the reports: how could it be created and increased in the face of risks and catastrophes? The fundamental concern would be the relationship established between "resilience" and "leadership" in order to deal with global risks and, finally, in keeping with the entrepreneurial model, drafting what would come to constitute an ontology of the resilient.

\section{In the Origins of Cataclysm and Biopolitics: State, Economy, and Science}

In 1968, the classic film by George A. Romero, The Night of the Living Dead, signaled a total revolution for the zombie genre (Russell, 2014), in its characterization of the living dead, in its exploration of causes, and in the images subsequent to the appearance of the monster. It is no accident that one of the main features of this change of focus was the question of the Mass, coinciding with the appearance of Ehrlich's book The Population Bomb (Ehrlich, 1970). The protagonist was no longer the Bokor, the evil voodoo priest who appeared in the early days of the genre, in relation with the US occupation of Haiti in 1915 (McAlister, 2012). Now it was the Mass and the terror it engendered (Mahoney, 2011) and, with that, characterization of the survivors, which enabled harsh criticism of the main repressive conditions of the time: racism, male chauvinism, and the power of the state. I shall discuss this bifurcated evolution in the next section which is concerned with the ontological template of the genre. For the moment, I am concerned to highlight the evolving exploration of causality and effects of catastrophe.

The resurrection of the dead in this film is vaguely related with the nuclear threat-the other great source of dystopian inspiration in the 20th century-but after the 2002 film, 28 Days Later by Danny Boyle, the genre headed off into the topos of infection (almost certainly influenced by the traumatic experience of the twentieth-century AIDS pandemic) and definitively displacing the extraterrestrial or nuclear types, while pointing to biomedical research for military ends as the main suspect, covered up for and protected by the state. Research into the origins of the cataclysm indicates three spheres: politics (incarnated by the state and army as its repressive apparatus), the economy (embodied by the big corporations), and science (especially biomedicine), and the intersections among the three domains. The twenty first-century zombie genre, making the most of a revamped plague metaphor, is defined by its exploration of the responsibility of these three spheres within the framework of immunology, as highlighted by Esposito (2011) and, at the same time, the condition of a world in which all three spheres collapse due to the disappearance or breakdown of the state, the loss of money value as a sign of the disintegration of the capitalist system, and the downfall of technology. In the first sphere, the repressive nature of the state and its apparatuses is laid bare, stressing its propensity for self-preservation rather than protecting the population for which it claims to be responsible. Globalization renewed fears about the concentration of economic power in the form of monopoly capitalism, a theme which is recurrent in zombie productions. Among them, the famous Resident Evil saga is the one that has gone furthest, tending to blame the mega-corporations -Umbrella-, the generators of necessary knowledge and, although curing human diseases and avoiding aging (or, if one prefers, leading the quest for immortality) may appear as noble ends which trigger the tragedy, the viewer can deduce that commercial success and elite interests have taken over and perverted the project. So, in the third sphere, the series of bird flu outbreaks in 2004 and 2005 and speculative manipulation of the situation to promote the antiretroviral business put the pharmaceutical industry on the list of villains.

From this standpoint, one might consider that the search for shared responsibilities for the uncertain origin of the plague is an exercise in emancipatory catastrophism since it is the catastrophe itself which invites one to recognize the functioning of the political order, its subordination to economic interests, the dangers of advanced knowledge of life (biopolitics), and also recognition of the state of exception as the norm. Ambiguity, heightened by a proliferation of doubles, is evident in the approach to seeking accountability for the zombie hecatomb: the two-faced state (protector and controller, executioner and victim of the apocalypse), the duality of corporations (able to make miracles possible and trigger the end of our days), and the twofold nature of knowledge itself a schizophrenic science incarnated in both the "mad scientist" (Newitz, 2006) and the struggle-usually by a female character-to find an antidote. Something similar might be said about conspiracy theories which 
adapt so well to screenplays and the plots of novels and, in their oversimplification and causality, so badly to reality. The crucial point, however, is the approach to governability, in all its crudeness, at the beginning of the twenty first century as a continuation of security devices applied to both population and territory, and mobilized on the basis of the state of exception and quarantine, whether it is the state which resorts to them or groups of survivors. The catastrophe may be an accident, a calculated aim from the start, or a decision that gets out of hand, but the question that crops up is who to save and who to sacrifice, making a clear separation between the resilient and the redundant. It is at this point that fictional work speaks of a mutation of biopolitics -as a way to rationalize the problems that arise in the practice of the government of living beings, constituted in population- into thanatopolitics: or what Foucault (1976a) referred to as "make live" and "let die." Unlike the first one that is obsessed with producing life and preserving it (Foucault, 1976b), the second decant the balance toward the consent, if not active production of death.

\section{THE ONTOLOGICAL APPROACH: FROM HOMO ECONOMICUS TO THE TRANSHUMAN}

\section{Technologies of the Self and the Resilient Subject}

The immense popularity of the zombie genre in the twenty first century, starting with comics and the television series of The Walking Dead, has been explained by some as a response to the climate of terror propagated after the 9/11 attacks (Bishop, 2010), from a stereotypically American viewpoint of the distortion of the "American dream" into a nightmare (Cantor, 2013). But the global scope of this success is not limited to its cathartic power in the face of growing insecurity, or to the influence of the threat of becoming redundant, but rather because it explores the model of neoliberal subjectivation based on resilience. It is an archetype that has gone beyond the Fordist "homo economicus" which ushered in the "productive subject," or the "entrepreneurial subject," or the "company man" (Laval and Dardot, 2009). The old calculating, productive individual promoted by Benthamstyle utilitarianism has been supplanted by an ideal type defined as a product of and for competition, the "entrepreneur" who acts as the connector of the group. With this change of direction, which means accepting entrepreneurship as a guide to behavior and self-exploitation as its first result, some writers like the philosopher Han (2017) have sought to see a rupture with the disciplinary order imposed by biopolitics. That is, neoliberalism appears as a cessation of liberalism that is linked to bio politics (Foucault, 1979), despite the fact that the market is maintained as a touchstone of government: neoliberalism has definitively transformed the technologies associated with bio politics. Thirdmillennium zombie stories are, more than anything else, a propaedeutic for leadership, establishing the group dynamics that will propitiate individual and collective resilience, and establish the innate and acquired condition.

The sine qua non condition of resilience is ability to accept the new rules of the game, of this new world steeped in violence resulting from competition and the constant threat of redundancy. Those who are unable to adapt are doomed to madness, to suicide, or to become infected. In order to prevail, survivors must become progressively desensitized and surrender to immanentism, as if there was no tomorrow (but with the sole aim of finding some infection-free territory in order to start over) and with no past (which must be overcome). Once the rules of the competition are accepted, the intrinsic value of each individual constituting a seed of resilience is nothing more nor less than talent as initial human capital (according to the theses of Becker, 1993). Talent is presented as an individual gift, sometimes masked by society or more precisely by the class position occupied by the individual in the pre-apocalyptic world. Now, exaltation of talent as true human nature tends to be constructed with claims to meritocracy, but from an anti-elitist position. It Moves up social mobility for resilience as a combined result of the "Talent" and "Effort," identified by Littler (2017) as the elements of the meritocracy defined by neoliberalism.

The real qualities needed for survival are not those recognized by a bureaucratized society. The underlying idea is that the zombie hecatomb brings with it a tabula rasa which enables reorganization (and purifying) of the social structure based on the innate value of each individual, with an emphasis on talent enabling him or her to struggle against chaos. Class differences are therefore dissolved and individualist meritocracy (rooted in human nature in the form of talent) comes to constitute the mainstay of resilience, a notion which, in fact, revives the survivalist genre in the United States.

But is talent enough? Resilience can also be learnt in the struggle against redundancy-against the zombies_-and fighting against other groups of survivors which can never be trusted. Competition (with its implicit inclusion of the use of violence) is the best school of resilience. Brown (2015) has observed that the alteration that neoliberalism has brought about in homo economicus, self-conceived as human capital in the context of risk-bound finance capital, means that the nucleus of the conception of the subject shifts from interest to sacrifice in the name of macroeconomic growth or higher credit as the only way of recovering. In the zombie genre, the idea of sacrifice is omnipresent: self-sacrifice for the resilience of others or for the population as a whole. This is clearly expressed in the novel World War Z, by Brooks (2006). It is no longer possible to protect everyone so only a part of the population will be saved in accordance with two parameters: first, contribution to recovery of the state and, second, social reproduction (including but not limited to biological reproduction). But, together with this decision, there is another which is even more instructive: when part of the (non-infected) population is sacrificed to save the other part. It is then that one sees that resilience is, at bottom, more a question of classificatory state action than of the individual's intrinsic nature represented by talent.

\section{Mutations of the Zombie: The Z-Topia of Non-subjects}

If, in the new millennium, the survivor has been a metaphor of resilience, the zombie obviously stands for redundancy. This excess population, according to Bauman (2003), would consist 
of individuals who are incapable of joining the job market, or of others who, once expelled from it, not only have no chance of getting back into it but do not even count as a reserve army of labor. Their main characteristic would be that of failed consumers. The malleability of the zombie has made it possible to develop the original germ of "surplus population" referred to by Marx in his criticism of Malthus and, moreover, to include the whole marginal population whose distinguishing feature would be stigmatization and alienation: from the slave (McAlister, 2012), to the proletarian (McNelly, 2012) by way of the infected. Yet, as inequality has expanded with globalization, the definition of redundant has also widened, to the extent that authors like ŽiŽek (2014), and Appadurai (2015), taking up the concept of "bare life" described by Giorgio Agamben (1998), consider that all those people who are relegated to the gray zone of the law, for example, refugees, forced migrants, child laborers, and people denied citizens' rights, would belong to the category. Other authors draw attention to expulsion (Sassen, 2014) and dispossession (Butler and Athanasiou, 2013), going beyond the strict labor market framework directly related with neoliberal policies.

However, the main feature of the living dead, at least since Romero, has been that of a body without a soul. Hence the revolutionary seed is that this creature cannot be a subject and, accordingly, cannot be subjected to the technology of power. Starting from a formless, contagious mass into which zombies mutated at the beginning of the millennium and which remains present in the greater part of the genre as the background for the competition among groups of survivors, three main branches have developed: progression of the Mass into the "Multitude" (the main representative of which is still the work of George A. Romero), the transhuman (the best example being the Resident Evil saga), and the post-human (who may be found in Melanie: The Girl with All the Gifts by McCarthy, (2016). All of them share the fact that, for the first time, there is an active attempt to identify the public with the monster. In the first case, this would be the result, already noted by Jameson (2010), of the transformation of the old theme of overpopulation and fear of the mob into a conceptualization of the "multitude," given this category by commons thinkers (Hardt and Negri, 2000). Although the line initially explored by George A. Romero in Land of the Dead (2005), in which he endowed zombies with a rudimentary form of communication, an Afro-American leader and an (armed) revolt, was abandoned by Romero himself, the popularization of "zombie parades," with their transversal rebellious spirit, would be the most eloquent expression of this developmental line. From the playful spirit of a handful of movie fans-as in Toronto in 2003-these processions have changed into a carnival-type protest in which the participants can be identified with the Mass at the same time as they uphold their own particular ruptures with the norm, challenging the patriarchy, monogamy, heterosexual hegemony and racial hierarchy (White, 2013). The culmination of this line might well be the zombie demonstrations, like that of October 4, 2011, organized by members of Occupy Wall Street, which rapidly multiplied inside and outside the United States and had their most recent expression in the " 1,000 Gestalten" zombie protest organized in Hamburg on July 5, 2017 prior to the G20 Summit. This line directly connects with identification of the zombie with redundancy, as a product of thanatopolitics understood as mass production of bodies without death in accordance with a sovereign decision, in this case, neoliberal policies (Lewis, 2011). This then leads to the formulation of "Z-topia" as a new topology of the revolution which can accommodate representation of the dispossessed beyond the subjectivation of multicultural neoliberalism in the messianic times wrought by the apocalypse.

The second evolutionary strain, which I have described as transhuman, is that represented by the heroine of the Resident Evil saga who is both infected and transgenic. A feminist interpretation of the story identifies this main character, Alice, as a cyborg capable of transcending gender roles, in the sense of Donna Haraway's A Cyborg Manifesto (2000), in which the use of violence is justified as a disruption of the patriarchal representation of the female gender and thus discarding the subordinate role of women (Harris, 2015).

Finally, the post-human line (Lauro and Embry, 2008) can be traced back to remote roots in the novel I Am a Legend by Richard Matheson (1954) and its film sequels in which the new race, in this case vampires emerging from the plague, must replace a humanity perceived as monstrous. The most recent version of this type is Melanie: The Girl with All the Gifts, a film adaptation of the novel by Carey (2014) in which the lead character, Melanie, represents a new species, a group of 2nd-generation hybrids engendered from a symbiotic relationship between the fungus that causes the zombie plague and humans.

\section{ARCHITECTURES OF THE FUTURE: POST-APOCALYPTIC TIMES}

With regard to future scenarios, the first peculiar feature of the zombie genre is the imposition of post-apocalyptic times or, in other words, it is no longer about waiting for a more or less imminent catastrophe but it is confirmation that the apocalypse has already occurred. This vision, heir of ecological consciousness pertaining to the Anthropocene epoch (Morton, 2013), reinforces the idea of living in a liminal time in which the world as we knew it has come to an end and, moreover, where humans are faced with a change in forms of government as well as in the very essence of the human being, revolving round the idea of catastrophe and how to pull through. In general terms, it refers to the disappearance of the future according to modernist design (Davies, 2018), replaced in this case by nomadism caused by the struggle for survival.

Unlike utopias, however, the models presented in order to define the conditions for constructing an ideal community are those of undesirable (anti-utopian) communities. The spatialization of the different models goes back to the idea of utopia as heterotopia. The most prolific example of this is The Walking Dead, which moves from the psychopathic tyranny of the Governor, based on the politics of bread and circuses, by way of the nostalgic autarchy represented by Hershel Green's farm, and through to the democratic community of Alexandriawhich fails because it is not exposed to the competition (the 
violence outside) or the "feminist" (and pacifist) community of "Oceanside," opposite to their image, represented by "The Scavengers," led by Jadis, as birds of prey that live among the remains of the modern world. The bad government that represents anti-utopian communities implies forms of political organization and alternative economies, sometimes similar to an ontogenic program, where it is necessary to return to precapitalist modes of production until reinventing them again. The return to order is thus, first and foremost, a way of ensuring the economy. Let's not forget that the image that synthesizes chaos is that of looting. The rebuilding of the political body, once the differing forms of tyranny have been rejected, clearly claim for a variety of post-politics: the disturbing conclusion is that democracy turns into consensus on leadership, or concerning the decisions the leader takes in the name of the group in order to survive so that the democratic will is expressed in a plebiscite of survival (and not in votes).

To the specialization of anti-utopias, it corresponds to a "post-apocalyptic demography," where what stands out, if we take as a paradigm The Walking Dead and the sequel Fear the Walking Dead, is the super diversity of liberal democracies (Vertovec, 2012). It is a representation that begins with the race and the historical load of the black/white categorization in American history and gives way to the inclusion of firstly the ethno-cultural groups that emerged mainly from Asian and Hispanic migration, and successively other groups based on sexual orientation, and disability, along with gender and age. This representation of diversity has its limit in that the established hierarchy maintains the white and heterosexual man as the leader of the surviving group, while women, gays and lesbians are accepted to the extent that they embody the viral values of violence-Inviting us to post-racial and postfeminist readings, in which feminism is still a relic of the past (Baldwin and McCarthy, 2013) —or that are legitimized by the exceptionality of the fight against redundancy, -that the case of gays appears as an example of what Puar (2005) called homo-nationalism, that is, the acceptance of the figure of the gay, in so far as it does not endanger in heteropatriarchal discourse by also making the values of competition and leadership.

The hope of finding a bigger group of survivors-frequently what is left of the state and, even more frequently, a new society begun and purified by resilience-is presented as the driving force of nomadism. The self-made frontier man of the Wild West is revealed here as the utopian horizon of neoliberalism. Up to a certain point, this may be seen as what Zygmunt Bauman called a "retrotopia" (2017), the nostalgia for freedom emerging from Darwinian competition as the founding myth of the American nation (and capitalism).

\section{DYSTOPIA AND EMANCIPATORY CATASTROPHISM}

What can dystopian thinking and emancipatory catastrophism contribute in this context? Playing the post-apocalypse game does lead us to an analytical method that allows vivisection of the neoliberal body. Or, as more optimistic observers might say, an autopsy on the corpse of late capitalism.

This means, in the "archeological" aspect, identifying and trawling, through to the bitter end, the values imposed by business management on institutions and individuals, from competition, by way of the transformation of the concept of leadership, through to classification of the population into "redundant" and "resilient." The production of redundancy ends up becoming a strategy for the resilience of the system so that it can perpetuate itself in endless transformation thanks to its principle of "creative destruction" which, here, means the dispossession of part of the population. The most thoughtprovoking aspect at this point is the centrality of a state which, although it appears to be weak and falling apart, still reserves its classifying powers as the bedrock of governability in the state of exception: being able to pronounce which part of the population can be dispensed with, namely the group which is at the core from the switch from biopolitics to thanatopolitics.

This makes it possible to understand the impact on the technologies of the self which produce subjectivation from the "ontological" standpoint, in relation with the technologies of power centralized in the market-society governments of the new millennium. On the one hand, the labeling of resilient and redundant appears and is revealed as a tautology since labeling an individual or group as resilient is precisely what enables survival. Hence, as Vint (2013) holds, zombies synthesize the crisis of contemporary subjectivity by reflecting the ease with which all of us can be displaced from the sphere of the bio-occupied by those who are integrated into the job and consumption markets as a way of life-into the domain of the zoe, in which we would belong to the category of economically irrelevant life.

Finally, in the "architectural" domain, the zombie genre makes it possible to explore the undesirable areas into which we are being led by the market society and, still more, to recognize the times in which we live as dystopian or even post-apocalyptic. The repertoire of anti-utopias can represent an inquiry into both characters to be avoided and spatialized forms of undesirable governments. But, above all, what it gives us as a model is the achievement of a post-racial and post-feminist world, in line with the program of what has been called "neoliberal progression" or, in terms of Jo Littler, the "liberal social version of neoliberalism."

\section{AUTHOR CONTRIBUTIONS}

The author confirms being the sole contributor of this work and approved it for publication.

\section{ACKNOWLEDGMENTS}

I would like to thank Michael Rodriguez for the invitation to participate in the session Apocalypse Now: The Rise and Resonance of Dystopic Imaginaries, of the 112th Annual Meeting 2017 of the American Sociology Association, and Scott Schaffer to encourage me to present my results in the journal Frontiers in Sociology. I also want to thank reviewers for their suggestions and observations that have not only substantially improved this text, but have also been very useful for future research. 


\section{REFERENCES}

Agamben, G. (1998). Homo Sacer. Sovereign Power and Bare Life. Stanford, CA: Stanford University Press.

Amin, A. (2012). Land of Strangers. Cambridge: Polity Press.

Appadurai, A. (2015). The Future as a Cultural Fact: Essays on the Global Condition. London: Verso.

Attenborough, D. (2011). This Heaving Planet. London: New Statesman.

Baldwin, M., and McCarthy, M. (2013). "Same as it ever was: saviour narratives and the logics of survival in the walking dead," in Thinking Dead. What the Zombie Apocalypse Means, ed M. Balaji (New York, NY: Lexington Books), 75-87.

Bauman, Z. (2003). Wasted Lives: Modernity and its Outcasts. Cambridge: Polity Press.

Bauman, Z. (2017). Retrotopia. Oxford: Polity Press.

Beck, U. (1986). Risikogesellshaft. Auf dem Weg in eine andere Moderne. Berlin: Suhrkamp Verlag.

Beck, U. (1994). "The reinvention of politics: towards a theory of reflexive modernization," in Reflexive Modernization. Politics, Tradition and Aesthetics in the Modern Social Order, eds U. Beck, A. Giddens, and S. Lasch (Stanford, CA: Stanford University Press), 1-55.

Beck, U. (2016). The Metamorphosis of the World. Cambridge: Polity Press.

Becker, G. S. (1993). Human Capital. Chicago, IL: Chicago University Press.

Bishop, K. W. (2010). American Zombie Gothic. The Rise and Fall (and Rise) of the Walking Dead in Popular Culture. Jefferson, NC; London: McFarland \& Company.

Bloch, E. (1995). The Principle of Hope. Cambridge, MA: MIT Press.

Bourdieu, P. (2012). Sur l'Êtat. Paris: Raison d'agir/Editions du Seuil.

Brooks, M. (2006). World War Z: An Oral History of the Zombie War. New York, NY: Crown Publishers.

Brown, W. (2015). Undoing the Demos. Neoliberalism's Stealth Revolution. New York, NY: Zone Books.

Butler, J., and Athanasiou, A. (2013). Dispossession: The Performative in the Political. Cambridge: Cambridge Polity Press.

Cantor, P. A. (2013). The apocalyptic strain in popular culture: the American nightmare becomes the American dream. Hedgehog Rev. 15, 23-33.

Carey, M. (2014). The Girl With all the Gifts. London: Orbit Books.

Davies, W. (2018). "Introduction to economic science fictions," in Economic Fictions, ed W. Davies (London: Goldsmiths Press), 1-28.

Domingo, A. (2008). Demodystopias: prospects of demographic hell. Popul. Dev. Rev. 34, 725-745. doi: 10.1111/j.1728-4457.2008.00248.x

Domingo, A. (2015). Migration as a global risk: the world economic forum and neoliberal discourse on demography. J. Quetelet 3, 97-117. doi: 10.14428/rqj2015.03.01.04

Ehrlich, P. R. (1970). The Population Bomb. New York, NY: Sierra Club.

Esposito, R. (2011). Bíos. Biopolitics and Philosophy. Minneapolis, MN: University of Minnesota.

Foucault, M. (1976a). Histoire de la sexualité 1. La volonté de savoir. Paris: Éditions Gallimard.

Foucault, M. (ed.). (1976b). "Bio-historie et bio-politique," in Dits et écrits II, 1954-1988, (Paris: Quarto, Gallimard), 95-96.

Foucault, M. (ed.). (1979). "Naissance de la Biopolítique". Annuaire du College de France, 79 année. Histoire des systèmes de pensé, année 1978-79," in Dits et écrits II, 1976-1988, (Paris: Gallimard), 818-825.

Foucault, M. (1988). Tecnologies of the Self. Boston, MA: University of Massachussets.

Fukuyama, F. (1989). The end of history? Natl. Interest 16, 3-18.

Gordin, M. D., Tilley, H., and Prakash, G. (eds.) (2010). "Utopia and Dystopia beyond space and time," in Utopia/Dystopia: Conditions of Historical Posibility, (Princenton, NJ: Princenton University Press), 1-17.

Han, B.-C. (2017). Psycopolitics: Neoliberalism and New Technologies of Power. New York, NY: Verso.

Haraway, D. (2000). "A cyborg manifesto: science, technology and socialistfeminist in the late twentieth century," in The Cybercultures Reader, eds D. Bell, and B. M. Kennedy (London; New York, NY: Routledge), 291-325.

Hardt, M., and Negri, A. (2000). Multitude: War and Democracy in the Age of Empire. Harvard, MA: Harvard University Press.
Harris, A. (2015). "Woman as evolution: the feminist promise of resident evil film series," in Race, Gender and Sexuality in Post-Apocaliptic TV and Film, ed B. Gurr (New York, NY: Palgrave-Macmillan), 99-111.

Huxley, A. (2004). Brave New World. London: Vintage.

Jameson, F. (2010). "Utopia as method, or the uses of the future," in Utopia/Dystopia: Conditions of Histrical Posibility, eds M. D. Gordin, H. Tilley, and G. Prakash (Princenton, NJ: Princenton University Press), 21-44.

Lauro, S. J., and Embry, K. (2008). A zombie manifesto: the nonhuman condition in the era of advanced capitalism. Boundary 2, 85-108. doi: 10.1215/01903659-2007-027

Laval Ch., and Dardot, P. (2009). La Nouvelle Raison du Monde. Paris: Éditions la Découverte.

Lepenies, W. (1988). Between Literature and Science: The Rise of Sociology. Cambridge: Cambridge University Press.

Levitas, R. (2013). Utopia as Method. The Imaginary Reconstitution of Society. New York, NY: Palgrave Macmillan.

Lewis, T. E. (2011). “Ztopia: lessons in post-vital politics in George Romero's zombis films," in Generation Zombie. Essays on the Living Dead in Modern Culture, eds S. Boluk, and W. Lenz (Jefferson, NC; London: McFarland and Company), 90-100.

Littler, J. (2017). Against Meriocracy. Culture, Power and Miths of Mobility. London; New York, NY: Routledge.

Lovelock, J. (2007). The Revenge of Gaia. London: Penguin Books.

Lovelock, J. (2010). The Vanishing Face of Gaia. London: Penguin Books.

Mahoney, P. (2011). "Mass psychology and the analysis of the zombie: from suggestion to contagion," in Generation Zombie. Essays on the Living Dead in Modern Culture, eds S. Boluk, and W. Lenz (Jefferson, NC; London: McFarland and Company), 113-129.

Manheim, K. (1936). Ideology \& Utopy. New York, NY: Harvest Book.

Mbembe, A. (2006). Necropolitique. “Traversées, diàspores, modernités”. Rais. Polit. 21, 29-60.

McAlister, E. (2012). Slaves, cannibals and infected hyper-whites: the race and religion of zombies. Anthropol. Q. 85, 457-486. doi: 10.1353/anq.2012.0021

McNelly, D. (2012). Monsters of the Market. Zombies, Vampires and Global Capitalism. Chicago, IL: Haymarket Books.

Morton, T. (2013). Hyperobjects. Phulosophy and Ecology after the End of the World. Minneapolis, MN: University of Minnesota.

Moylan, T. (2000). Scraps of the Intainted Sky. Science Fiction, Utopia, Dystopia. Boulder, CO; Oxford: Westview Press.

Newitz, A. (2006). Pretend we're Dead. Capitalist monster in American Pop culture. Durham; London: Duke University Press.

Noxolo, P., and Preziuso, M. (2013). Postcolonial imaginations: approaching a "fictionable" world through from the ovels of Maryse Condé and Wilson Harris. Ann. Assoc. Am. Geogr. 103, 163-179. doi: 10.1080/00045608.2011.628251

Orwell, G. (ed.) (2000). "Nineteen eighty-four", in The Complete Novels, (London: Penguin Classics), 741-925.

Puar, J. (2005). Queer Times. Queer Assemblage. Duke: Duke University Press.

Richard Matheson. (1954). I am a Legend. New York, NY: Gold Medal.

Russell, J. (2014). Book of the Dead. The Complete History of Zombie Cinema. London: Titan Books.

Sassen, S. (2014). Expulsions: Brutality and Complexity in the Global Economy. Harvard, MA: Harvard College.

Schlosser, K. (2015). Apocalyptic imaginaries, Gramsci, and the last man on Earth. Geohumanities 1, 307-320. doi: 10.1080/2373566X.2015.1096749

Southerland, J.-A., and Feltey, K. M. (2013). Cinematic Sociology: Social Life in Films. Thousand Oaks, CA: Sage.

Strauss, K. (2015). These overheating worlds. Ann. Am. Geogr. 105, 342-350. doi: 10.1080/00045608.2014.973805

United Nations, Department of Economic and Social Affairs, Population Division. (2017). World Population Prospects: The 2017 Revision, DVD Edn.

Vertovec, S. (2012). "Diversity" and social imagery. Eur. J. Sociol. 53, 287-312. doi: 10.1017/S000397561200015X

Vint, S. (2013). “Abject posthumanism: neoliberalism, biopolitics, and zombies," in Monster Culture in the 21tst Century. A Reader, eds M. Levina, and D. T. Bui (New York, NY; London: Bloomsbury), 133-146.

White, M. (2013). "Killing whiteness: the critical positioning of zombie walk brides in internet settings," in Monster Culture in the 21tst Century. A Reader, eds M. Levina, and D. T. Bui (New York, NY; London: Bloomsbury), 209-225. 
Wilson, J., and Swyngedouw, E. (eds.). (2014). "Seeds of dystopia: post-politics and the return of the political," in The Post-Political and Its Discontents: Spaces of Despolitization, Spectres of Radical Politics, (Edimbourgh: Edimbourgh University Press), 1-22.

World Economic Forum (2012). Global Risks, 2012. Geneva: World Economic Forum.

World Economic Forum (2013). Global Risks, 2013. Geneva: World Economic Forum.

World Economic Forum (2015). Global Risks, 2015. Geneva: World Economic Forum.

World Economic Forum (2016). Global Risks, 2016. Geneva: World Economic Forum.

World Economic Forum (2018). Global Risks, 2018. Geneva: World Economic Forum.
Zamyatin, Y. (2006). We. New York, NY: Harper Collins Publishers.

Žižek, S. (2014). Trouble in Paradise: From the End of History to the End of Capitalism. London: Allen Lane, Penguin.

Conflict of Interest Statement: The author declares that the research was conducted in the absence of any commercial or financial relationships that could be construed as a potential conflict of interest.

Copyright (c) 2018 Domingo. This is an open-access article distributed under the terms of the Creative Commons Attribution License (CC BY). The use, distribution or reproduction in other forums is permitted, provided the original author(s) and the copyright owner(s) are credited and that the original publication in this journal is cited, in accordance with accepted academic practice. No use, distribution or reproduction is permitted which does not comply with these terms. 